JOURNAL OF SECURITY AND SUSTAINABILITY ISSUES

ISSN 2029-7017 print/ISSN 2029-7025 online

2019 June Volume 8 Number 4

http://doi.org/10.9770/jssi.2019.8.4(16)

Scopus

\title{
NATIONAL SECURITY MAINTENANCE BY LEGAL MEASURES: CASE STUDY LITHUANIA/UKRAINE
}

\author{
Andrejus Novikovas ${ }^{1}$, Agnė Tvaronavičiene் ${ }^{2}$, Roman Shapoval ${ }^{3}$ \\ ${ }^{12}$ Mykolas Romeris University, Ateities st. 20, 08303, Vilnius, Lithuania \\ ${ }^{3}$ Yaroslav Mudryi National Law University, Dynamivska st. 4, 61023, Kharkiv, Ukraine

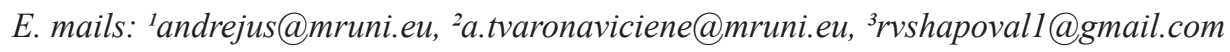

Received 12 March 2018; accepted 8 April 2019; published 30 June 2019

\begin{abstract}
The purpose of this article is to fulfil a comparative study of national security legislation, as well as the formation of conceptual foundation for its development and the elaboration of proposals for the improvement thereof with regard to Ukraine. The article analyses in comparative aspect the practice of the Republic of Lithuania as one of the European countries. In the context of globalization, the research focuses on international legal systems of both international and regional levels. The comparative legal analysis of the legal measures to maintain national security revealed similarities in theoretical and methodological approaches. In the study, the author's definition of national security is given; and a typological model of the concept of national security is formed.
\end{abstract}

Keywords: national security, public safety, threats to national security, principles of public safety.

Reference to this paper should be made as follows: Novikovas, A., Tvaronavičiené, A., Shapoval, R. 2019. National Security Maintenance by Legal Measures: Case Study Lithuania/Ukraine, Journal of Security and Sustainability Issues 8(4): 737-748. http://doi.org/10.9770/jssi.2019.8.4(16)

JEL Classifications: D73, H83

\section{Introduction}

According to Z. Zeibote, T. Volkova and K. Todorov (2019) economic interconnectedness is the prime mover of globalization. Still for the fast development and growing competitiveness of the country in the global market preserving of the national security becomes a corner stone of country's welfare. An economy crisis and post-crisis period is worldwide described as slimming era (because of necessary measures taken to optimize oversized processes and activities in order to minimize costs) (Jankelová et al 2018). In the public area, managing the national security crises often requires even more. It is necessary to reconsider the existing legal and institutional framework, identify weaknesses of the system and relocate resources. The situation becomes even more complicated, when the cyber security aspects are taken into consideration. Even well developed and well self-protected from the view of traditional national security issues countries, are facing new threats, because everything that uses technologies are based on communication and information systems depends on cyber security (Limba et al. 2017; Tvaronavičienė M. 2018; Davidavičienè et al. 2019).

National security issues are connected as well with sustainability and social cohesion problems (Prause et al 2019; Prakash, Garg 2019). It is challenging to stay independent, developing and able to interconnect in case there is serious threats from the externals. These arguments proves interdisciplinary origin of the issue and encourages scientist to focus on the researching of the main aspects of national security ensuring. 
The relevance of the study of the issues of legal support to national security, for the Ukrainian state, is determined primarily by the modern realities of the geostrategic position of the country and new perspectives in the development of the system of international relations, as well as the rapid and major changes in the socio-political structure of the country. The formation of the Ukrainian sovereignty is accompanied by an unexpected intensification of dangerous military instability both inside the country and abroad. Ukraine today has no potential to guarantee the safety of its democratic gains and statehood from all possible threats and crisis situations (Katchanovski 2015). The state is not always ready to consistently protect itself from possible wars and conflicts, to detect and predict the development of new and existing threats in a timely manner. Overall, theoretical comprehension of the means and methods of ensuring the national security of Ukraine is required, taking into account the international legal arsenal.

For the research, the Republic of Lithuania has been chosen intentionally, as long ago, before Lithuania became a member of transatlantic organizations, it had faced similar geopolitical issues. During the period from before NATO membership till now Lithuania has accumulated good practice in the field of national security that can be shared. Many scientists have discussed matters of legal support to national security on actively in recent studies. Steven Weber (2015) dedicated his work to administrative and legal support to national security at potential war. Gonzalo Ruiz Diaz (2017) examined an administrative support to security in public-private partnership. Cary Coglianese (2015) discussed matters of administrative law in the USA and beyond. John W. Palmer, J.D. (2010) analysed issues of national security in the context of financial crisis. Barry Buzan (2008) performed international security studies in the post-cold war era. Many researchers continue to search for the most optimal national security-supporting model.

Modern scholars discuss matters of national security legislation in close connection to the administrative, constitutional, criminal, criminal procedure, and other kinds of law to ensure national security. An essential regulative role of the provisions of law is revealed in the papers addressing the concept and mechanism of maintenance of certain types of national security: economical, military, informational, environmental, and others. However, these studies address issues of legal measures to maintain national security merely in fragments.

In our opinion, it is crucial that in Ukraine, the effect of legal regulation upon maintenance of national security and effectiveness thereof is not yet scientifically researched. The study is directly related to the main directions of scientific support to the implementation of Ukrainian national strategies and laws in this field.

The goal of this article is to develop a science-based system of legal means to ensure national security. Developing of it would allow to use positive foreign experience in the Ukrainian environment; and for the European Countries, the results would inspire national legislators to bring into practice new ideas and options for their implementation. The research was fulfilled using scientific literature and document analysis as well comparative and case study methods.

\section{Issues of National Security Concept}

Use of the term "administrative and legal measures" in relation to maintenance of national security is determined by the fact that the area of public administration in both Ukraine and Lithuania does not possess a sufficient degree of normativity, and is characterized by significant variability of social relations caused by the emergence of new security threats. Legal science and international legal instruments not yet sufficiently clarify the definition of the concept of national security; furthermore, there is no sufficient clarity in other definitions as well.

National security concept can be used in several points of view: scientific, political and public, so often the interpretation of it is different. From a public point of view, this term is understood as the preservation of the country's independence and its defence against foreign threats. Political approach interprets national security as a protection and defence of the independence of the state, territorial integrity and constitutional order thereof from various threats arising both from outside and inside of the state (see Law on the Basics of National 
Security of the Republic of Lithuania 1997). From a scientific point of view, there is a very large variety of definitions of this term. Barry Buzan considers a concept of security „the essentially contested” due to its nature (Buzan 2008), because national security includes the whole range of public and social phenomena and different security levels. Summarising the variety of views and approaches, the researcher states that national security involves the concept of state and public security, i.e. their ability to protect their national independence, and territorial integrity as possibility to the members of the society to live and develop (Buzan 2008).

In general, the definition of national security concept is very complex. The European Court of Human Rights (hereinafter referred to as ECHR) confirms this. It is impossible to fully describe the concept of national security. It can be very wide, leaving a wide margin of discretion to the relevant authorities to define what is needed for this particular security. In addition to the well-known national security areas / types (economic, military, informational, ecological, and others), it is possible to distinguish the status of foreigners, whose presence in the state poses a threat to national security. For instance, the Law on the Legal Status of Foreigners in the Republic of Lithuania (2004) does not identify what can be considered a threat to the national security. ECHR has noted that Article 8 of the European Convention on Human Rights (1953) does not compel States to enact legal provisions listing in detail all conduct that may prompt a decision to expel an individual on national security grounds. The Court stated that threats to national security may vary in character and may be unanticipated or difficult to define in advance (see C.G. and others v. Bulgaria, 2008).

The energy sector could be distinguished as another important area of national security. According to the Law on the Basics of National Security of the Republic of Lithuania (1997), the energy sector of the economy is of strategic importance to national security and provision of energy supplies may not be placed under the control of the entities of the supplying countries. The Constitutional Court of the Republic of Lithuania stated that: „the special legal regulation consolidated in the LNG Terminal Law attempts to create the legal preconditions for installing and operating a concrete LNG terminal of strategic significance to national security, through which it would be possible to supply all consumers of Lithuania with energy resources (natural gas) and thus to end the dependence on the sole monopolist external supplier of such energy resources. In guaranteeing the security of the supply of natural gas in Lithuania, the legislature has created the legal preconditions for ensuring the interest of the entire society to receive energy resources from multiple sources under non-discriminatory conditions and, by such legal regulation, it implemented the duty consolidated in Paragraph 3 of Article 46 of the Constitution to regulate economic activity so that it serves the general welfare of the nation" (2015).

Scientists alongside the traditional security sector offer to distinguish communication security sector as well, elements of which ensure the information security sector in the system. Scientists believe that the threat to communication sector should be defined as a threat to traditional public relations and communication processes (Janeliūnas 2004)

Analysis of the national security sphere requires defining and establishing the circle of social relations that makes up its contents, and which includes the relations listed in the Figure 1.

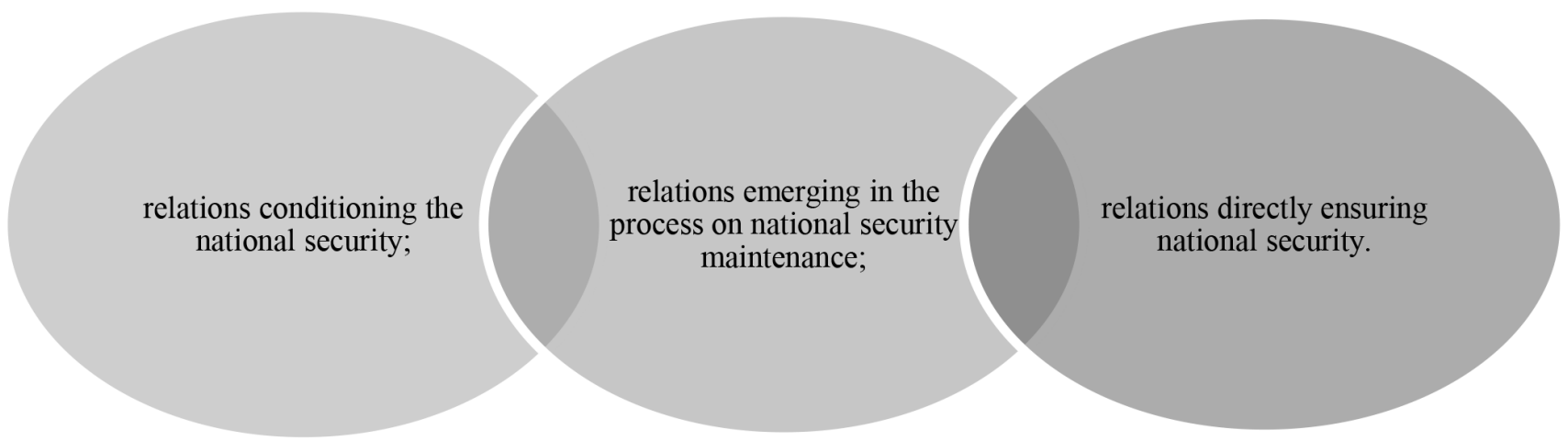

Figure 1. Relations that make up the contents of national security. 
The issue of clarification of the concept of national security has almost never been investigated in the legal literature. In this case it is necessary to proceed from International Covenant on Civil and Political Rights, adopted by the UN General Assembly on 16 December 1966. It states that each state undertakes "to ensure that any person whose rights or freedoms as herein recognized are violated shall have an effective remedy, notwithstanding that the violation has been committed by persons acting in an official capacity". The absence or failure of security endangers the very existence of human and the state intended to guarantee it. The concept of security is a complex legal institution, describing the organization of the protection of the vital interests of the individual, society and state from internal and external threats (Ashmini et al 2015). It should be noted that the "security" is associated with the object carrier thereof. Thereby private, public, and state security shall be distinguished; together that make up such a category, as national security. Wherein, the complexity of the concept of national security allows creating of a typological model consisting of the following three components, which are shown in Figure 2.

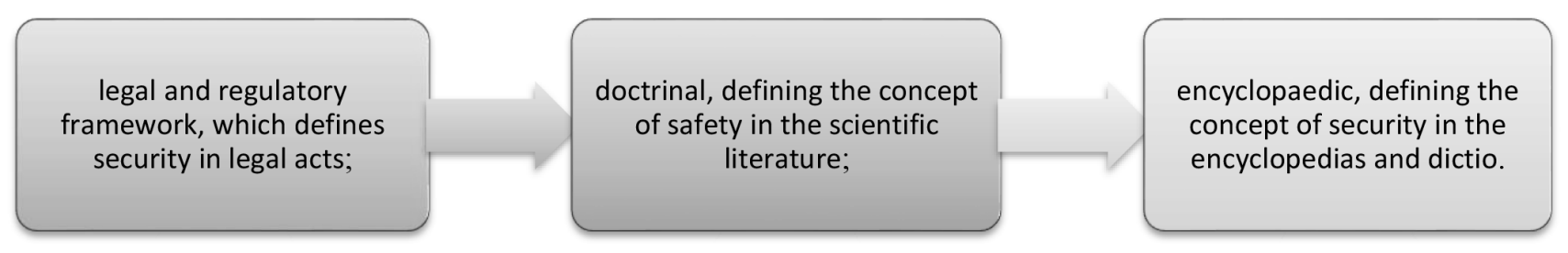

Figure 2. The typological model of the concept of national security.

The presence of the following approaches is common to these three components: static - a state of safety; apophatic - an absence of threats; and passive - a compliance with regulations.

International provisions of the legislation of the US and Eastern Europe, established and sanctioned by the state, define the system of internal and external environment, preventing threat to a person. The implementation of these standards in public relations is the main content of the national security (Weber 2015).

The legal impact on national security is intended to guide the subject's behaviour by establishing the general rules that define how to behave in specific cases, the prohibitions of committing illegal acts, the application of sanctions to the subjects in the case of violation of the prohibitions. Together with that, legal rules govern the organization and activity of bodies of state power and local self-government on national security (Chapman 2014). The purpose of national security in the countries of Eastern Europe and the United States is to protect the personal, political, social and economic rights of human and citizen, interests of society and the state (Márquez 2015).

\section{Relation between national security and other "related" categories}

The relationship between the concepts of national security and the rule of law is of a theoretical and practical interest.

Investigating the relation of law and order and national security at the international level, it is necessary to take into account all aspects of social ties and relationships. The properties of these categories have much in common: they are interpenetratable and dependent; and formed almost on the same principles; and intertwined with the state authorities and local self-government (Bustikova 2015).

According to experts, national security and the rule of law are of the same functional legal burden, the result of which is the implementation of the rule of law in the protection of life, health, honour and dignity of citizens; the provision of public safety; the formation of a regulatory environment for enterprises, institutions and organizations of different forms of ownership (Wang \& Madson 2013). National security and the rule of law act as the general and the particular as in the event of violation of the law the relations connected with national security are violated as well. The rule of law is an integral part of national security. This integrity allows the 
experts to examine the external and internal communications, ensuring the interaction of the individual, the society, and the state (Palmer 2010).

The analysis of the legislation shows that the national security, public order, and public safety appear as closely related and interdependent, but not identical categories. For example, the similarity of national security, public order and public safety can be seen in the following:

- national security, public order and public safety are complex social phenomena based on a certain set of social relations, which are protected by social norms. The most significant and numerous relations are governed by the rule of law. Uniformity of social relations that make up the content of each of the phenomena under consideration and settlement thereof by specific sets of legislation acts allow us to consider the latter as independent complexes, legal institutions; and concepts denoting thereof as cross-sectoral legal categories;

- general principles grounding national security, public sign of order and public safety in the state include: rule of law, stability and warranty, the mutual responsibility of the individual, the society, and the state in the field of security, and respect for the balance of the vital interests of the individual, the society and the state;

- it is difficult to identify the relationship of national security, public policy or public safety that would exist in isolation. In any set of social relations, those that give this set of qualitative certainty always dominate.

Therefore, the scope of national security and public safety may also include relations specific to public order; however the last in this area are of secondary importance, and does not determine its nature. In such cases, a violation of public relations at the same time influences the attitudes of public order (Diaz 2016).

The similarity and affinity of the nature of national security, public safety and public policy categories are noted by the Court of Justice of the European Union (hereinafter referred to as CJEU) (H. T. v. Land BadenWürttemberg 2015). The Court has already had the opportunity to explain the concepts of "public security" and "public policy" as established by Directive 2004/38, Articles 27 and 28. While this Directive aims to purposes other than Directive 2004/83, and although the Member States in accordance with their national needs, which can vary, depending on the Member State and the period in principle, are free to define the requirements to public policy and public security (P.I. v Oberbürgermeisterin der Stadt Remscheid 2012 paragraph 23, and cases cited therein), the protection of these main interests which the society seeks to give them, cannot vary according to the legal position of the offender.

The term ,public security“, as it is understood by Directive 2004/38 part 3 Article 28, includes both external and internal safety of a member state (see, inter alia, paragraph 43 of Decision in Land Baden-Württemberg v Panagiotis Tsakouridis 2010, and cases cited therein), therefore threat to the functioning of institutions and essential public services as well as survival of the population, and a risk of significant negative impact on external relations or the peaceful coexistence of nations and threat to military interests might affect public safety (paragraph 44 of Land Baden-Württemberg v Panagiotis Tsakouridis, 2010).

It should also be noted that the term "public policy" as used in Directive 2004/38, in particular Articles 27 and 28 , is clarified by the CJEU so that in any case it means that, in addition to the social order perturbation caused by any violation of the law, there is a real, present and sufficiently serious threat to a fundamental interest of society (see, inter alia, paragraph 40 of the decision in Byankov case (Hristo Byankov v Glaven sekretar na Ministerstvo na vatreshnite raboti, 2012) and cases cited therein).

The following features serves as the basis for the distinguishing of public policy, public security, and national security:

1. The specificity of social relations that constitute the national security, public policy and public safety. At the heart of those or other social relations there are social needs (interests) that influence the development of those particular relations.

2. The difference in the regulation measures.

3. Substantial differences in the nature of violations of public policy and public safety. 


\section{Systems of Ukrainian and Lithuanian authorities to ensure national security}

The Law On National Security of Ukraine (2018) defines the framework and principles of national security and defence, the goals and basic principles of state policy, structures the system of subordination in the security and defence sector, as well as the command, control and coordination system of the security forces and defence forces and development directions of strategic plans, providing protection for a person and a citizen.

In accordance with the mentioned Law, the President of Ukraine exercises control over the security and defence sector both directly and through the National Security and Defence Council headed by him. Cabinet of Ministers of Ukraine exercises control over the observance of legislation and implementation of state policy in the areas of national security and defence. This body reports on these issues, to the President of Ukraine and the Verkhovna Rada of Ukraine, and provides civilian control over the activities of executive authorities, that are part of the security and defence sector of Ukraine.

On the basis of the analysis of domestic legislation and international legal instruments it should be stated that a system of state support for the national security of Ukraine, consists of a subsystem of democratic civil control, which is subject to the state of law and order, staffing, state and activity of security and defence bodies, as well as the content and state of implementation strategies, doctrines, concepts, government programs and plans in the areas of national security and defence, and the management subsystem of the security and defence sector. The structure of the national security system must include the following subsystems of state support to national security as it shown in Figure 3.

\begin{tabular}{|c|c|c|}
\hline \multicolumn{2}{|c|}{ SUBSYSTEM OF DEMOCRATIC CIVIL CONTROL } & $\begin{array}{c}\text { MANAGEMENT SUBSYSTEM } \\
\text { OF THE SECURITY AND DEFENCE SECTOR }\end{array}$ \\
\hline $\begin{array}{l}\text { by the President of } \\
\text { Ukraine }\end{array}$ & $\begin{array}{l}\text { by the Cabinet of Ministers } \\
\text { of Ukraine }\end{array}$ & $\begin{array}{c}\text { the President of Ukraine } \\
\text { (carries out direct management of the security and defence sector) }\end{array}$ \\
\hline $\begin{array}{c}\text { by the Verkhovna Rada } \\
\text { of Ukraine }\end{array}$ & by the executive authorities & $\begin{array}{l}\text { the National Security and Defence Council } \\
\text { (carries out coordination of the security and defence sector, } \\
\text { in the event of a martial law or a state of emergency, coordinates } \\
\text { the activities of executive bodies in a special or military period) }\end{array}$ \\
\hline $\begin{array}{l}\text { by the National Security } \\
\text { and Defence Council of } \\
\text { Ukraine }\end{array}$ & $\begin{array}{c}\text { by local self-government } \\
\text { bodies }\end{array}$ & $\begin{array}{l}\text { Ministry of Defence of Ukraine (is the main body in the system } \\
\text { of central bodies of executive power, which ensures the formation } \\
\text { and implementation of state policy on issues of national security } \\
\text { in the military sphere, defence and military construction } \\
\text { in the peacetime and special period) }\end{array}$ \\
\hline by the courts & $\begin{array}{c}\text { by citizens, both personally and } \\
\text { through public associations or } \\
\text { deputies of local councils }\end{array}$ & \\
\hline \multicolumn{3}{|c|}{ THE STRUCTURE OF THE NATIONAL SECURITY AND DEFENCE SECTOR } \\
\hline \multicolumn{2}{|c|}{ Security forces } & Defensive and industrial complex \\
\hline \multicolumn{2}{|c|}{ Defence Forces } & $\begin{array}{l}\text { Citizens and public associations } \\
\text { that volunteer to participate in national security }\end{array}$ \\
\hline
\end{tabular}

Figure 3. System of the state support of national security of Ukraine.

In addition, this body cannot be chaired by the President of Ukraine, which forms the national security policy and actually controls themselves by the NSDC constituting the head thereof. Under such conditions, system of checks and balances in the area of national security is broken, which means that none of the national security entities can be authorized more than others, and each of them should have the right impact in this area at each other. This is due to the fact that the President's of Ukraine preferential authority in personnel matters should not determine their priority in the formulation, implementation and monitoring of the implementation of national security policy. As the effectiveness of the control is directly associated with the known subordination of those supervisory bodies, as their belonging to the president's "frame of reference" or to any executive authorities makes an effective control impossible. 
Like Ukraine, the Republic of Lithuania has formed its own system of the institutions involved in ensuring the national security. The Law on the Basics of National Security of the Republic of Lithuania (1997) provides for the state agencies, maintaining national security. They are classified as follows in Figure 4.

\begin{tabular}{|c|c|c|}
\hline \multicolumn{3}{|c|}{ MANAGING AUTHORITY } \\
\hline $\begin{array}{l}\text { President of the Republic } \\
\text { of Lithuania }\end{array}$ & Seimas of the Republic of Lithuania & Government of the Republic of Lithuania \\
\hline \multicolumn{3}{|c|}{ EXECUTIVE AND OTHER AUTHORITIES } \\
\hline $\begin{array}{l}\text { Lithuanian Ministry of } \\
\text { Foreign Affairs }\end{array}$ & Lithuanian State Defence Council & $\begin{array}{l}\text { Ministry of Defence and other NDS institutions } \\
\text { subsidiary to Defence Minister }\end{array}$ \\
\hline The Army & The State Security Department & $\begin{array}{c}\text { Ministry of Internal Affairs, the police, the State Border } \\
\text { Guard Service and other management agencies } \\
\text { of the Ministry's sphere of ensuring public security }\end{array}$ \\
\hline $\begin{array}{c}\text { The Special Investigation } \\
\text { Service }\end{array}$ & $\begin{array}{l}\text { Other ministries and state and municipal } \\
\text { authorities in accordance } \\
\text { with their competence }\end{array}$ & \\
\hline
\end{tabular}

Figure 4. Subsystems of the state support to national security of the Republic of Lithuania

The President of the Republic is one of the subjects ensuring national security and developing Lithuania's national security system. President of the Republic also heads the State Defence Council, is one of the highest governing bodies, which manages national security (Law On the Basics of National Security 1996).

Lithuanian Supreme Administrative Court (hereinafter referred to as SACL) indicated that independence and freedom of action of the President of the Republic performing the functions assigned to it in accordance with the Constitution and the oath are undoubtedly a matter of national security. Attempts to restrict the President's autonomy, threats or blackmail to force the President to perform certain actions, especially if such actions are illegal, violate the Constitution and (or) the laws, poses a real and tangible threat to national security(Lithuanian Supreme Administrative Court, 2010).

Lithuanian State Defence Council (functions of which are defined by the Law on the State Defence Council (1993)). The Council considers the most important issues of national security. For example, foreign and domestic policy provisions guaranteeing the Lithuanian national security and territorial integrity, as well as key national security policy and defence principles, and directions; provides recommendations to the President, the Seimas and the Government upon conclusion, signing and ratification of international treaties, agreements in defence and other military issues, coordinates activities of state agencies related to national security; considers the state defence issues, the main provisions of preparation for the mobilization; approves intelligence needs and priorities; determines the strategic guidelines for crisis management etc.

Some politicians proposed to amend Article 140 of the Constitution (1992) and other legislation relating to the State Defence Council (Paulauskas 2015). The amendments were intended to replace the current State Defence Council with a National Security Council, which is common to other European Union and NATO countries. According to the initiators (Paulauskas 2015) State Defence Council reform was necessary because the current name of the Council, its competence, the issues and the composition did not meet contemporary national security needs, particularly in view of the current geopolitical situation. National security is a broader concept that includes not only the military defence of the state, but foreign policy as well, including stability of the internal political, economic and social systems, advanced development of the state. Under the existing competence, the State Defence Council is currently not in a position to consider these broad questions.

Following the practice of other EU and NATO countries, the National Security Council consists of politicians. According to the initiators, Councils of no less than 14 EU Member States, are composed of top political officials in relation to national security, and non-politicians take managerial positions (chiefs of armed forces, heads of intelligence services). These usually are not permanent members of the Security Council, but have the right to attend meetings of the Council, and to advice. Current Law on State Defence Council (last amendments 
made in 2012) gives the Council broader functionality than paragraph 1 of Article 140 of the Constitution; therefore doubts raise as to whether the Council can, under the Constitution, as specified by law, consider and co-ordinate national security issues. In practice, such cases have occurred, but under the Constitution, the competence of the Council on these issues could be doubted (Paulauskas 2015).

The analysis of the Lithuanian authorities to ensure national security (or participating in ensuring national security) system, emphasizes that the Law On the Basics of National Security of the Republic of Lithuania (1997) provides that „Lithuania's national security system shall be based on the activities of state institutions and participation of every citizen of Lithuania, on the open civic society aware of dangers and its responsibility, civic-minded and prepared to defend Lithuania's freedom“. Human and citizen's rights and freedoms as well as personal security are indicated as one of the main objects of national security, while the citizens, their societies and organisations together with the State, its institutions of national security and defence and other institutions are named as the entities ensuring national security. The law establishes direct dependence and their interaction of Lithuanian national security system and civil society. This makes the base for democratic national security policy objectives, implementation of the tasks, formation and development of civil society.

\section{National and international levels of maintaining national security}

A characteristic feature of the legislative acts of foreign states is the reception of international law in domestic legal systems. Thus, according to Art. 25 of the Basic Law of the Federal Republic of Germany (1949) "general rules of international law are an integral part of the law of the Federation. They have the advantage over the laws and directly create rights and duties for the inhabitants of the federal territory." Thus, there is a combination of national law and international law with the primacy of the latter.

Basics of legal measures to ensure national security at the international level are considered by many researchers on the grounds of constitutional statutes of different states that form the basic platform for its regulatory and legal support, in relation to the activities of law enforcement bodies. As rightly noted by experts, the legislation of the UK, Hungary, Spain, Italy, Canada, Germany, France, Japan and other countries contains certain contradictions in national security and respect for human rights and freedoms; this contradiction is determined by the collision of the collective and individual interests of human communities (Merrill, Watts 2002). However, in respect of a single person, ensuring their personal and collective security in the society of their kind should be regarded as their most important right. In some cases, the international instruments do not contain any specific wording on this issue; however, the analysis of the Universal Declaration of Human Rights and Freedoms (1948), International Covenant on Economic, Social and Cultural Rights (1966) and other instruments has revealed that this is not quite correct. Among the human rights and freedoms, international instruments refer to freedom and security of person, the right to just and favourable conditions of work, the right to free development of personality rights in the economic, social and cultural fields, the right to an adequate standard of living, physical and mental health etc. Comparison of these rights with the directions of national security in various areas gives an indication that the purpose of national security can be traced, first of all, in the establishment of the minimum conditions necessary for the realization of these rights (Mashaw, Merrill 1985).

Considering the international legal instruments, we can note the comprehensive nature of the right to international security (Coglianese 2015). International legal regulation of activity of states to ensure the international rule of law is essential for strengthening their national security. At the same time, regional security is essential for national security at the international level, and threats to the regional security are threats to the vital interests of individual states (to their territorial integrity, sovereignty, domestic legal policy). The comparative legal analysis of the legal measures of national security maintenance in the USA and Eastern European countries showed common theoretical and methodological approaches to the development of national legislation and other regulations in the field of national security (Bird, Wallich 1993).

In addition, it should be noted that the state, which belongs to one or another international organization, whose aim is promotion of international security, should not pay less attention to internal national security. SACL 
noted that merely becoming of the Republic of Lithuania a member of North Atlantic defensive alliance and, since May 1, 2004 a member of the European Union by itself cannot eliminate threats to national security. Lithuanian state security is concerned not only with external threats, which may actually be reduced to some extent by becoming a member of relevant international and supranational organizations, but also with the country's inside processes, appropriate activity of public authorities, especially those with a very significant role in ensuring national security. According to paragraph 4 of part I of the Appendix to the Law on the Basics of National Security (1997), measures of internal policy are also important in ensuring national security, and pursuant to point I of paragraph 10 of part II of the mentioned Appendix, one of the national security measures is an activity of national security institutions. Inappropriate domestic policy in general can stimulate the inner turmoil, damage to the public (society) safety, lead to social and economic or other forms of pressure, threats to economic or other interests, to undermine the prestige of state government as a constitutional state regime element and public confidence in it. So unacceptable effects on the relevant authorities and political processes making or planning such an effect may pose a threat to national security and to the Republic of Lithuania's accession to the relevant international and supranational organizations (Lithuanian Supreme Administrative Court ruling, 2010).

The Court has also stated that following the National Security Strategy (2002) (version of the 2005), paragraph 1.4, as a member of the North Atlantic Treaty Organisation and the European Union, the Republic of Lithuania shall perceive its national security as a constituent part of the security policy of these Organisations. Furthermore, according to the National Security Strategy paragraph 3.1, vital interests of the Republic of Lithuania are as follows: sovereignty, territorial integrity and democratic constitutional order of the Republic of Lithuania; civil society, respect and protection of human and civil rights and freedoms; peace and prosperity of the State. It is obvious that these interests may be threatened and undermined even after Lithuania's accession to the North Atlantic defence alliance and the European Union.

With reference to the international experience, it should be noted that national security on the one hand, acts as the legal basis for the functioning of the government, on the other hand, it occurs and exists where and when the government is interested in it (Coglianese 2001). It is an authority that establishes and maintains security, safeguards against violations; and, where necessary, protects as well. In the system of state power, its executive branch realises a significant amount of authority for the formation of national security and, obviously, the greatest amount of authority for its maintenance, conservation, and protection.

Domestic political decision determines to a great extent which model (towards domestic policy, in order to limit the vulnerability of the state, or towards the country's foreign policy, to reduce the external threat and affect its sources) to focus in the fight against threats. Improper political solution in the evaluation of the threat would not increase the country's national security, but on the contrary, it would reduce it. By the way, the threat is not a fixed thing, it is constantly changing. For this reason, some threats arise, other decrease. For example, when in Lithuania industrial output significantly reduced, the ecological situation of the country improved. So again the measured decision is needed to determine what resources to the ecological security of the country may be downsized and transferred to the economic recovery of the industry. Consequently, every threat must be constantly monitored and evaluated (Nazelskis 2001).

As a threat to national security could be anywhere, it is necessary to set limits below which the threat has to be regarded as limited, should only be monitored, and above that limit the threat is a real danger to national security. Excessively active national security policy leads to a drain of resources, danger of public paranoia. Too passive policy is dangerous as it may be not possible to face the risks on time, or it may need to use a very large resource to defeat the threat. Therefore, the threat to be evaluated not only by the authorities, which carries the evaluation out, but also the methodology is needed, with the help of which it would be implemented. So threats determine the insecurity of the state and thus condition and define the content of national security, so they can assist in identifying the place of public education in the whole national security system and its impact on the security of the country. 
The study of legal measures to maintain national safety in Eastern Europe and the United States leads to the conclusion that the reform of the national security agencies in Ukraine can be carried out taking into account the positive experience of foreign countries in the development of state security systems and modern global trends of the development of such systems by the following: to prioritize preventive measures and strategies (Reinsch 1909); to strengthen the role of the state bodies and institutions to provide security and counter internal and external threats to national security in the field of national security, to strengthen cooperation with foreign countries; to improve anti-terrorism and counter-intelligence activities; to keep the regime of protection of state secrets; to concentrate intellectual, financial and other resources in priority areas of national security in the field of state safety; to increase the level of the budget and other forms of resource provision of the national security entities.

\section{Conclusions}

The comparative legal analysis of the legal measures to maintain national security in the Eastern European countries revealed similarity in theoretical and methodological approaches to the development of national legislation and other regulations in the field of national security.

1. Author's definition of national security. National security means a protection of the vital interests of the individual, society, and state against external and internal threats, which is achieved by using a system of political, economic, organizational, legal, military, ideological, and other measures adequate to the threat to the vital interests of individuals, society and the state, and which provides their sustainable progressive development.

2. The typological model of the concept of national security is formed, which consists of the following elements: - legal and regulatory framework, which defines security in legal acts;

- doctrinal, defining the concept of safety in the scientific literature;

- encyclopaedic, defining the concept of security in the encyclopaedias and dictionaries.

The presence of the following approaches is common to these three components: static - a state of safety; apophatic - an absence of threats; and passive - a compliance with regulations.

3. Maintenance of national security means activities of specified range of subjects that have real capabilities (authority, resources) to protect the vital interests of the individual, society, and state against external and internal threats through the use of the system of political, economic, organizational, legal, military, ideological, and other measures, adequate to the threat to the vital interests of the individual, society and state in specific historical conditions of development of the state and society.

4. Analysis of the legislation has revealed that national security, public policy, and public safety appear as closely related and interdependent, but not identical categories.

5. International legal regulation of activity of states to ensure the international rule of law is essential for strengthening their national security. At the same time, regional security is essential for national security at the international level, and threats to the regional security are threats to the vital interests of individual states (to their territorial integrity, sovereignty, domestic legal order).

\section{References}

Ashmini, G. K. et al (2015). National Security and Domestic Terrorism: The US Case, International Encyclopedia of the Social \& Behavioral Sciences (Second Edition): 247-252. https://doi.org/10.1016/B978-0-08-097086-8.45071-3

Basic Law of the Federal Republic of Germany (1949). https://www.bundesregierung.de/breg-en/chancellor/basic-law-470510

Bird, R. \& Wallich, C. (1993). Fiscal decentralization and intergovernmental relations in transition economics: Toward a systematic framework of analysis. The World Bank. http://documents.worldbank.org/curated/en/311571468739162484/pdf/multi0page.pdf 
Buzan B. (2008). People, States \& Fear: An Agenda for International Security Studies in the Post-Cold War Era. London: ECPR press. C.G. and others v. Bulgaria (2008). ECHR, Application No. 365/07, 24 July 2008.

Chapman, B. (2014). U.S. Department of Justice. Legal Authorities Supporting the Activities of the National Security Agency Described by the President. http://purl.access.gpo.gov/GPO/LPS66493

Coglianese, C. (2015). Administrative Law: The United States and Beyond. International Encyclopedia of the Social \& Behavioral Sciences (Second Edition): 109-114. https://doi.org/10.1016/B978-0-08-097086-8.86001-8

Constitution of the Republic of Lithuania (1992). http://www3.lrs.lt/home/Konstitucija/Constitution.htm

Davidavičienė, V., Raudeliūnienė, J., Tvaronavičienė, M., Kaušinis, J. (2019). The importance of security aspects in consumer preferences in electronic environment, Journal of Security and Sustainability Issues 8(3): 399-411. http://doi.org/10.9770/jssi.2019.8.3(9)

Decision of Lithuanian Supreme Administrative Court (2010) in the administrative case no. A-858-1810/2010.

Diaz, G. R. (2017). The contractual and administrative regulation of public-private partnership, Utilities Policy 48:109-121. https://doi. org/10.1016/j.jup.2016.04.011

Directive 2004/38/EC on the right of citizens of the Union and their family members to move and reside freely within the territory of the Member States amending Regulation (EEC) No 1612/68 and repealing Directives 64/221/EEC, 68/360/EEC, 72/194/EEC, 73/148/EEC, 75/34/EEC, 75/35/EEC, 90/364/EEC, 90/365/EEC and 93/96/EEC (2004). https://eur-lex.europa.eu/legal-content/GA/ TXT/?uri=CELEX:32004L0038

Directive 2004/83/EC on minimum standards for the qualification and status of third country nationals or stateless persons as refugees or as persons who otherwise need international protection and the content of the protection granted (2004). https://eur-lex.europa.eu/ legal-content/EN/TXT/?uri=celex\%3A32004L0083

European Convention on Human Rights (1953). https://www.echr.coe.int/Documents/Convention_ENG.pdf\%23page=9

H. T. v. Land Baden-Württemberg (2015). CJEU, C373/13. http://curia.europa.eu/juris/liste.jsf?language=en\&jur=C,T,F\&num $=\mathrm{c}-373 / 13$

Hristo Byankov v Glaven sekretar na Ministerstvo na vatreshnite raboti (2012). CJEU, C249/11. http://curia.europa.eu/juris/liste. jsf?language $=$ en $\&$ num $=C-249 / 11$

International Covenant on Civil and Political Rights (1966). https://treaties.un.org/doc/publication/unts/volume\%20999/volume-999-i14668-english.pdf

International Covenant on Economic, Social and Cultural Rights (1966). https://www.ohchr.org/en/professionalinterest/pages/cescr. aspx

Janeliūnas T. (2004). Saugumo studijos - grịžimas prie objektyvistinio analizès modelio [Studies of Security - coming back to the model of objective analyses], Politologija. 2(34): 40-71.

Jankelová, N. et al (2018). Security of the business organizations as a result of the economic crisis, Entrepreneurship and Sustainability Issues 5(3): 659-671. https://doi.org/10.9770/jesi.2018.5.3(18)

Katchanovski, I. (2015). Terrorists or national heroes? Politics and perceptions of the OUN and the UPA in Ukraine, Communist and Post-Communist Studies, 48(2-3): 217-228. https://doi.org/10.1016/10.1016/j.postcomstud.2015.06.006

Land Baden-Württemberg v Panagiotis Tsakouridis (2010). CJEU, C-145/09. https://eur-lex.europa.eu/legal-content/EN/ TXT/?uri=CELEX\%3A62009CJ0145

Law on National Security of Ukraine (2018). https://zakon2.rada.gov.ua/laws/show/2469-19

Lietuvos Respublikos ịstatymas dèl užsieniečių teisinès padèties (2004). [Law on the Legal Status of Foreigners in the Republic of Lithuania]. Valstybès žinios, 2004-04-30, No. 73-2539.

Lietuvos Respublikos Konstitucinio Teismo nutarimas "Dèl suskystintų gamtinių dujų terminalo projekto ịgyvendinimo ir finansavimo" (2015) [Decision of the Constitutional Court of the Republic of Lithuania "In regard of the implementation and financing of the liquefied natural gas terminal project"]. TAR, 2015-04-03, No. 5147.

Lietuvos Respublikos laikinasis valstybès gynimo tarybos įstatymas (1993) [Temporary law on The State Defence Council]. Valstybès žinios, No. 20-493. 
Lietuvos Respublikos nacionalinio saugumo pagrindų įstatymas (1997) [Law on the Basics of National Security of the Republic of Lithuania]. Valstybès žinios, 1997-01-08, No. 2-16.

Limba, T. et al (2017). Cyber security management model for critical infrastructure, Entrepreneurship and Sustainability Issues 4(4): 559-573. https://doi.org/10.9770/jesi.2017.4.4(12)

Márquez, D. (2015). Mexican administrative law against corruption: scope and future, Mexican Law Review 8:75-100. https://doi. org/10.1016/j.mexlaw.2015.12.004

Mashaw, J. L. \& Merrill, P. (1985). Administrative law the American public law system: cases and materials. Eagan: West Publishing Company.

Merrill, T.W. \& Watts, K.T. (2002). Agency rules with the force of law: The original convention, Harvard Law Review 467-592. https:// doi.org/10.2307/1342610

Nacionalinio saugumo strategija [Strategy of national Security] (2017). Valstybès žinios, 2002-06-07, No. 56-2233. https://www.e-tar. lt/portal/lt/legalAct/TAR.2627131DA3D2/asr

Nazelskis E. (2001). Visuomenès švietimas ir nacionalinis saugumas [Public Education and National Security]. ACTA PAEDAGOGICA VILNENSIA, 8: 58-63.

P.I. v Oberbürgermeisterin der Stadt Remscheid (2012). CJEU, C348/09. http://curia.europa.eu/juris/liste.jsf?num=C-348/09\& language $=\mathrm{EN}$

Palmer, J. W. (2010). Administrative Law. Constitutional Rights of Prisoners (Ninth Edition), New York: Routledge. https://doi. org/10.4324/9781315722061

Paul A. et al (2015). International Perspectives on Security in the Twenty-First Century. Security Supervision and Management (Fourth Edition: 581-615. https://doi.org/10.1016/B978-0-12-800113-4.00043-2

Paulauskas A. (2015). Vietoj Valstybės gynimo tarybos siūloma kurti Nacionalinio saugumo tarybą [Instead of State Defence Council it is Proposed to Establish National Security Council]. http://www.infoteise.lt/kiti/aktualijos/135-vietoj-valstybes-gynimo-tarybossiuloma-kurti-nacionalinio-saugumo-taryba

Prakash, R., Garg, P. (2019). Comparative assessment of HDI with Composite Development Index (CDI), Insights into Regional Development 1(1): 58-76. https://doi.org/10.9770/ird.2019.1.1(5)

Prause, G. et al (2019). Between sustainability, social cohesion and security, Regional development in North-Eastern Estonia, Entrepreneurship and Sustainability Issues 6(3): 1235-1254. https://doi.org/10.9770/jesi.2019.6.3(13)

Reinsch, P.S. (1909). International Administrative Law and National Sovereignty. The American Journal of International Law, 3(1): 1-45. https://doi.org/10.2307/2186206

Tvaronavičienè, M. (2018). Towards internationally tuned approach towards critical infrastructure protection, Journal of Security and Sustainability Issues 8(2): 143-150. https://doi.org/10.9770/jssi.2018.8.2(2)

Universal Declaration of Human Rights and Freedoms (1948). https://www.un.org/en/universal-declaration-human-rights/

Wang, C., Matson, H. (2013). The curious case of Ai Weiwei and administrative law. Inside China's Legal System: 211-239. https://doi. org/10.1533/9780857094612.3.211

Weber, S. (2015). National Security Studies and War Potential of Nations, International Encyclopedia of the Social \& Behavioral Sciences (Second Edition): 253-256. https://doi.org/10.1016/B978-0-08-097086-8.93080-0

Zeibote, Z. et al (2019). The impact of globalization on regional development and competitiveness: cases of selected regions, Insights into Regional Development 1(1): 33-47. http://doi.org/10.9770/IRD.2019.1.1(3)

Andrejus NOVIKOVAS is Associate Professor of Public Law Institute at Mykolas Romeris Law School of Mykolas Romeris University, Lithuania and attorney at Law. Research interests: national security, administrative law, legal regimes, public law.

Agnė TVARONAVIČIENĖ is Associate Professor and Director of Public Law Institute at Mykolas Romeris Law School of Mykolas Romeris University, Lithuania. Research interests: public law, national security, public procurement law, alternative dispute resolution.

Roman Volodymyrovich SHAPOVAL is Professor at the Department of Administrative Law and Administrative Activities at Yaroslav Mudryi National Law University, Ukraine. Research interests: public law, administrative law, national security. 